\title{
Tervikupüüe ja fragmendihirm Johannes Semperi loomingus
}

\author{
MERLIN KIRIKAL
}

Johannes Semperi (1892-1970) kuni Teise maailmasõjani kirjutatud teostes torkab silma tema esteetiline programm. See on seotud millegi tervikliku ja orgaanilisega, st elusale loodusele - Semperi loomes eriti taimsele - taandatavaga (nt Semper 1927a: 11, 21). Kui kunstiteos ei ole terviklik, ei ole selle vorm ja sisu sulandunud loomulikult ning see on „laboratoorlikult” osadeks lagundatav, seega mitteorgaaniline: abstraktsete, keeleuuenduse tarvis loodud tehislike sõnadega koormatud tekstis laiuvad Semperi sõnul „klorofüllita laigud” (Semper 1927a: 12, 21-22). Semperi jaoks sarnase sisuga mõisted orgaaniline ja terviklik tähistavad tema silmis väärtuslikke abstraktseid ja raskesti kokkuvõetavaid nähtusi. Näiteks on terviklik/orgaaniline „vaimse” inimese elu, milles ühinevad filosoofia, kunsti ja teaduse harrastus; elu igakülgse kogemise kaudu sündinud looming ning n-ö valdkonnaülesed sulandumised, sealhulgas luule side moraali, filosoofia ja iluga (Semper 1910/11: 450-453). Samu sõnu on Semper kasutanud kriitikas: XX sajandi alguse eesti kirjandust nimetas ta fragmentaarseks ja kobavaks, mitteterviklikuks (Semper 1927a: 11). Selle põhjusena nägi ta eelkõige sõdade ja revolutsioonide räsivat toimet, mis muutvat kirjanike hingeelu liiga analüütiliseks, mittelooduslikuks, mis omakorda pärsib loome terviklikkust (Semper 1927a: 7, 26). Seega kasutas ta neid mõisteid oma esteetiliste valikute põhjendamiseks. Semperi meelest on võimalik luua terviklikke kunstiteoseid, arendades eri valdkondade teadmisi ja oskusi, sulandades järjekindlalt tundmusi, tahet, mõistust - elades terviklikku elu. Käesolevas artiklis selgitangi sellise esteetilise programmi kujunemislugu, eritledes terviklikkuse ja orgaanilisuse väärtustamise filosoofilisi tagamaid ning olustikulisi tõukejõude. Ühtlasi vaatlen nende märksõnade valguses Semperi loomingut iseloomustavat vormikultust, keskendudes nii tema stiili- kui ka kehaideaalidele.

\section{Terviku märksõna filosoofiline kontekst Semperi loomingus}

Orgaanilisuse ja terviklikkuse poole püüdlemine on mõistetav Henri Bergsoni (1859-1941) filosoofia taustal, millest Semper oli kujunemisjärgus tugevalt haaratud (Semper 1978: 186, 190). Semperi päevikust ega memuaaridest ei selgu, millal ja miks ta Bergsoni esimest korda luges. Erna Siiraku (1969: 33) väitel tutvus ta Bergsoni ideedega Peterburis eradotsent Ivan Lapšini loengutes sealses ülikoolis aastatel 1910-1914 germaani-romaani keeli studeerides. Bergsoni intuitsiooni ja sisemise läbielamise ideid kasutas Semper oma seminaritöös saksa romantismist ja sümbolismist, mis ilmus esseena ajakirjas Noor-Eesti (Semper 1910/11). Peale selle koostas ta Bergsoni filosoofia teemal kaks referaati (Semper 1915a, 1915b). Semper polnud 
oma huvis üksinda. Bergsoni ideed mõjutasid mitmeid tollaseid kultuuri- ja teadusnähtusi, vormides ka kirjandusliku modernismi ${ }^{1}$ palet (Armstrong 2005: 13).

Semperi romaani „Kivi kivi peale” (1939) peategelane Joel Hurt loeb õhinaga Bergsoni peateost „Loov evolutsioon” („L'Évolution créatrice”, 1907, e k 2005) ning selle head tundmist mainib Semper oma memuaarides (1947: 57, 1978: 190). „Loov evolutsioon" sobitub XIX sajandil aktuaalseteks muutunud evolutsiooniteooriatega, millest mõjukaima on loonud Charles Darwin („Liikide tekkimine”, 1859). Bergsoni keskseks ideeks on elu kui katkematu voog (pr élan vital). XX sajandi alguse lääne kultuuris rohke kõlapinnaga „Loovas evolutsioonis” väidab Bergson, et kõike olevat tõukab pidevalt edasi eluhoog, seesmine surve (Bergson 2005: 68, 100-101, 113; Ott 2009: 99-100). Eluhoog on kestev liikumine, mida saab tõlgendada olemuslikult tulevikulisena, ehkki see polnud tingimata Bergsoni tees. Nii inspireeris Bergson futuriste ja suunas ka Semperit tulevikulise - ees seisvat elevalt ootava, progressiusulise, dünaamilise - elukäsituse poole.

Samas ei või Bergsoni mõtteid seostada ainult edasitõttamisega. Tema teostes on oluline mineviku, oleviku ja tuleviku ahel ning nende sulandumine, st nähtuste ajaline seotus ehk kestus (pr durée) (Bergson 2005: 22, 2006: 160). Bergson seostas aja konkreetse individuaalse läbielamisega, mis on mineviku-oleviku-tuleviku teljel laialivalguv (vt täpsemalt allpool). Semper kirjeldab sellist aja kogemist algtõelisusena, millenagi, mida teadvus otsekohe annab (Semper 1910/11: 454). Eri aegade sulandumine ehk durée kordub Semperi loomes ahela-, kee- või ketimotiivina, mis osutab sellele, et tähtis pole mitte eraldatud ese või konkreetne hetk, vaid nähtuste üksteisele eelnevus ja järgnevus, nende orgaaniline seotus. Näiteks Semperi debüütnovellikogus „Hiina kett” (1918) moodustavad armastajad omavahel ihakette (üks armastaja liigub teise rüppe, teine jällegi kolmanda juurde jne). See vihjab kire igikestvale ning edasi liikuvale olemusele (Kirikal 2020). Tegemist on leebe allusiooniga Arthur Schnitzleri skandaalsele näidendile „Ringmäng” („Reigen”, 1900), milles seksuaalpartnerid selguvad ringmängu põhimõttel (Undusk 1997: 664-666). Osadest (helmeist) saab tervik (kee) ka Semperi luules: „Vallatuses helmeid / pillud, mida mina lükin keeks?” (Semper 1917: 25) Ühtlasi näeb Semper (1919: 7) ketina kunsti kui nähtust üldiselt.

Seda järjekindlat ketistamist ja olemist kui sulandumist võimaldab Bergsoni filosoofia järgi intuitsioon, millega adume oma orgaanilist terviklikkust (Gillies 2003: 107). Eluhoogu, mineviku-oleviku-tuleviku paratamatut seotust ja iseend tajutakse intuitiivselt. Eeltoodu on nii Semperi loomingu kui ka kirjandusliku modernismi ja

\footnotetext{
${ }^{1}$ Kirjandusliku modernismi mõiste koondab sarnaste temaatiliste, tunnetuslike, jutustamistehniliste ja stilistiliste omadustega tekste, mis kirjutati XX sajandi alguses. Selle eristamine teistest nn ismidest on keeruline, eriti arvestades, et mitmed tavapäraselt modernismiga seostatavad tunnused (nt süžee puudumine, teadvuse vool, individuaalse taju esiletõus sotsiaalse miljöö kirjeldamise asemel jms) on olemas juba kirjanduslikus dekadentsis (vt Lyytikäinen jt 2020: 258). Eesti kultuuris on modernismi problemaatika põhjalikumalt läbi arutamata, paradoksaalselt on enam uuritud postmodernismi (Ojam 2018: 541). Eelkõige on eesti modernismi seostatud teatud poeetiliste tunnustega või kasutatud seda mõistet konkreetse epohhi tähistamiseks. Nõustun Indrek Ojamiga (2018: 541, 555), et eesti kirjandusliku modernismi mõtestamiseks tasuks ilukirjanduslikke tekste uuesti lugeda, olles tundlik selle suhtes, kuidas ja miks on need tekstid ise modernismiga suhestunud.
} 
selle ühe (ehkki mitte ainult modernismile omase) nõude alus: teose sisu ja vorm on tihe lahutamatu orgaaniline tervik (Gillies 2003: 108). Selline kunstikäsitus ei levinud aga alates Bergsonist, vaid juba palju varem. Näiteks oli see võtmemõisteks saksa romantikutele, kelle orgaaniline eluvaade ja keelemõtestus mõjutasid ka Bergsoni (Posman 2013: 217).

Semperi huvi saksa romantismi vastu sai samuti alguse Peterburis (Semper 1978: 186). Tema esteetilisi tõekspidamisi, sh kehamõtestust vormis romantismi üks tunnetuslik kiud ehk organitsism, mille sündi seostatakse muu hulgas Jakob Böhme vitalismi ja sellest lähtuva mittemehhaanilise mõttelaadi levimisega Saksamaal ja Prantsusmaal (Kermode 2004 [1957]: 114). Organitsistlikule filosoofiale, st inimtekkeliste nähtuste seostamisele orgaanilise ainega ning oleva tajumisele organismina, panid aluse Goethe ja Herder XVIII sajandil, kui leidis aset epistemoloogiline pööre (Fairer 2009: 16; Walzel 1965 [1932]: 19-20). Just siis sai senise füüsika asemel põhiliseks teaduseks bioloogia ning kõige põnevamad avastused tehti väidetavalt just selles vallas. Pöördepunktiks peetakse Herderi ideid, eriti tema vastandumist looduse mehhaanilisele mõtestamisele. Loodust, sh inimest tuleks Herderi meelest mõista taime eluprotsessi kaudu: nii nagu taim kasvab, vastab välistele stiimulitele, kikitab end ülespoole, imab vedelikku, on ka inimene oma keskkonnaga seotud. Nii nagu taime ei saa osadeks lahutada ilma teda vigastamata, on ka inimene mõtete, tunnete, tahete orgaaniline kooslus. (Abrams 1971 [1953]: 204-205) Esteetilise organitsistliku vaateviisi aluseks oli biologismi (s.o inimelu selgitamine bioloogia kaudu) domineerimise mõjul levinud uskumus, et luule peab olema loomulik/looduslik, mitte kunstlik. Sellises esteetikas on kunstiteos ainuvõimaliku vormi - mis tekib iseeneslikult justkui seestpoolt - väljendus. (Fairer 2009: 16) Organitsistlikule autentsele vormile vastanduv mehhaaniline vorm tekib aga siis, kui materjal surutakse ettemääratud piiridesse (vt Bergson 2005: 55). Tervikus peaksid osised sulanduma, mitte masinlikult kombineeruma. Positiivsed on seega läbielatav, pidev saamine ja bergsonlik intuitiivsus (Semper 1915b: 211).

Semperi teadlikkus organitsismist tuleb ilmekalt välja essees „Sümbolismus ja Saksa romantismus”, kus torkavad silma väljendid „organiliselt ühte sulama”, „üksus, organismus”, „organiline ühendus” (Semper 1910/11: 450-453). Seda esseed on ta ka põhjalikult redigeerinud ja selle uuesti avaldanud. 1919. aastal ilmunud versioonis, uue pealkirjaga „Romantika hing”, mainib Semper esmakordselt uurijaid, kelle töödest ta ammutas teema lahkamiseks vajalikud teadmised ja esteetilised väärtushinnangud: Oskar Walzel, Richarda Huch, Marie Joachim, Jean-Édouard Spenlé, Viktor Žirmunski, Karl Joël ja Isaac Rouge (Semper 1919: 18). Semper kasutab jõuliselt bergsonismi ja organitsismi sõnavara ja hinnanguid. Selgitades vaimu ja keha ning sisu ja vormi dünaamikat, peab ta nende loomuliku sulandumise parimaks kaasaegseks näiteks plastilist tantsu, seades selle eeskujuks teistelegi kunstivormidele. Just tantsijatar suudab oma etteastega keha vahetult hingestada ja hinge kehastada (Semper 1919: 99) ning see peaks olema iga kunstivormi ülim siht. Seetõttu, nagu allpool näitan, kehastab just tantsijatar tervikuiha elus ja kunstis, mis vastandub fragmendihirmule. Viimane on kriitiline suhtumine eri ühiskondlikesse ja kultuurilistesse nähtustesse (nt sõjad ja revolutsioonid, kiirustamine ja produkt- 
sioonihimu), mida Semper nägi vaimselt pärssivatena. Fragmendihirm on Semperi ja tema tegelaste põlgus- ja pelgustunne aineliste põhjuste tõttu häirunud kirjanduskultuuri ning selle fragmentaarse tundelise aluse vastu, mis irrutab „kõik üksikosiks: tundmus, mõistus, hing, vaim" (Semper 1927a: 7, 17).

Kuidas aga mõista fragmendihirmu leevendavat terviklikkust/orgaanilisust Semperi loomes? Miks valis Semper ühe esseekogu pealkirjaks „Näokatted” (1919) ja miks kubiseb tema luulekogu „Pierrot” (1917) commedia dell'arte'likest motiividest? Semper ja tema kirjanduslikud alter ego'd näivad igatsevat isikupärase, loomuliku eksistentsi järele. Nii ilmneb järjepanu, et moodsad naised ja mehed ei ole ehedad, mistõttu ei jõua Semperi meespeategelased ega Semper ise implitsiitse autorina nendeni tõeliselt (emotsionaalselt, verbaalselt, kehaliselt). Ka see võis tuleneda Bergsoni filosoofiast. Viimane väidab teoses „Sissejuhatus metafüüsikasse” („Introduction à la métaphysique”, 1903) mina kohta järgmist: „Kui ma olen tegevuseta ja lasen enda peal ringi käia teadvuse sisemisel pilgul, siis täheldan ma kõigepealt pinnal jäigastunud koorikuna kõiki tajusid, mis tulevad talle ainelisest maailmast. [---] Nende hästi väljalõigatud kristallide ja pindse jäätumise alt leian ma voolamisepidevuse, mis pole võrreldav millegagi, mida ma olen näinud mööda voolavat." (Bergson 2007: 1747) Bergsoni käsitluses on mina üheks osaks tardunud, stabiilne ja eri seisundeid kõrvutav pinnakiht ehk parasiitmina, mida esitatakse välismaailmale (Bergson 2006: 119-120). Selle katte all pulbitsevad eri minad, mis vastanduvad, sulanduvad ja edasi tõttavad ning mille Margus Ott (2009: 93-94) on tabavalt tõlkinud „süvaminaks”. Bergsonlik täielik mina on pindmiste ja sügavate kihtide kooslus (Bergson 2006: 120; Ott 2009: 94).

Bergsonlik minakäsitus on Semperile tähtis: tardunud kooruke on murekoht. Semperi tegelased näevad vaeva, et pealmist kihti ära pühkida ja leida orgaaniline süvamina (st autentsus, loomulikkus). Eriti kehtib see tema „Armukadeduse” (1934) peategelaste suhteis. Romaan kujutab eesti üliõpilase ja riigiametniku Enn Maiste ning jõuka pärija ja oma aega seltskondlike tegevustega sisustava Krista Leetmaa armastuslugu, mida vahendab minategelane Enn kümne aasta möödudes. Romaani pealkiri viitab mõlema armukadedusele: Enn tundis kiivust Krista endise kallima, tenor Viktor Lingi vastu ning Krista Ennu pikaaegse sõbratari, klaverikunstnik Herma Uustali vastu. Enn üritas meeleheitlikult Kristat tõeliselt mõista ja endale võita. Samas märgib ta sageli, et nn päris-inimest, eht-Kristat oli võimatu kätte saada (nt Semper 1934: 12). Minade haaramatuse teema Semperi loomes viitab ihale kogeda elu, kaasinimesi ja loomingut tervikliku, eheda, sügavana.

Semperi tekstides on terviklik/autentne ja fragmentaarne/võlts - mis võivad tähistada nii minaloomet, inimsuhteid, kehalisi hoiakuid, kunsti kui ka üldisemat elulaadi - omavahel kahtlemata pingelises suhtes. Vastuolu tekib Semperi tervikuja tulevikuusu tõttu, kuid see komplitseerub, kui kiigata manifesteeritud tervikuiha taha. Semperi esseedes, kuid eriti tema fiktsionaalsete meestegelaste sõnades-tegu-

\footnotetext{
${ }^{2}$ Commedia dellarte motiive leidub hulgaliselt Semperi ja teiste modernistide, nt Tuglase, Igor Stravinski, Edgar Degas', Ado Vabbe teostes. Semperi loomes motiveerib nende kasutust eelkõige tajumus, et moodsad inimesed etendavad rolle ja kannavad maske, kaugenedes ehedast olemisest (vt Undusk 2009: 501).
} 
des võib lugeja tajuda eheduse kadu. See tuleb esile väljajättude, vaikuste kaudu, olles hoolikalt progressiusu ja tulevikuhõllanduse varjus. „Armukadeduse” Enn rõhutab Krista minevikku suunatust ja vastandab sellele enda tulevikulisuse, väites, et tal puudub (romantiline) minevik. „Krista vaevles siis oma mineviku pärast, tundsin ma. Tal oli vahest küllalt kurbi kogemusi, aga kuidas need võisid üldse koormaks saada? Mis jaoks kõhelda, mis jaoks oma sisemusest üles otsida mingid varjud? Seisis ju meie ees uus tee lahti - ainult seda mööda astuda - kui kerge see ometi oleks!" (Semper 1934: 94) Lugeja teab Ennust vähe. Ennu enese loo lünklik kujundamine, mis toetub kohati narratiivsetele väljajättudele ja iseenesestmõistetavate seikade vältimisele (päritolu, õpingute sisu, vanemad jms), on XX sajandi alguse ilukirjanduse oluline märk (vt Johnson 2017: 4). Tollastes teostes esinevat fragmentaarsust, eriti just perekondliku kuuluvuse, pärinemise ja järglaste saamise asjus, on seostatud (sõja tõttu) lõhutud maskuliinse identiteediga. Tegelaste taustainfo katkendlik esitus osutab füüsilistele vigastustele, moonutustele ja haigustele, mis kaasnesid Esimese maailmasõja seninägematu vägivallaga. (Johnson 2017: 6-7) Nii tingivad tervikuiha ka konkreetsed materiaalsed olud.

Esimene maailmasõda mõjutas tollast elu nii määravalt, et sõjaaegset ja -järgset ilukirjandust võib õigustatult lugeda sõjatraumade või -mõjude analüüsina, seda ka juhul kui sõda otseselt ei kujutata (Tate 2013: 10). Ka Eesti kultuuriloos on Esimene maailmasõda tähenduslik, ehkki seda mõistetakse siin ja Ida-Euroopas üldiselt „unustatud sõjana”. Eestist mobiliseeriti mehi idarindele ning eestlased (nende hulgas Johannes Semper) olid tegevad ka tagalas. (Kivimäe 2015: 26-27) Esimene maailmasõda murdis tugevalt mehelikkuse norme, kangutades mehed lahti terviklikust tunnetusest, st tajust, et nende mina on koherentne ja kuulub ümbritsevaga kokku. Võimalik, et see oli esmajoones sõda, mis tekitas lagunemistunnet, mille tagajärjel kandsid sõjast (otse või kaude) mõjutatud meestegelased tervikliku ja orgaanilise maailma üle naistegelasse ja tema kehasse, samuti rangetesse stiilinõuetesse.

\section{Esimene maailmasõda ja Semperi modernsed meestegelased}

Peale organitsismi ja bergsonismi ideede on Semperi loomingu tervikupüüe ja fragmendihirm seotud sõjatraumadega. Tervikupüüe, mis enne Esimest maailmasõda oli olnud vaid kunstiline tõekspidamine, sai sõja järel terveoleku, rahu ja mentaalse stabiilsuse märgiks. Kuidas sõjakogemus vormis meheks olemise kujutamist? Kuidas säilitada bergsonlik eluhoog ning põimida minevik-olevik-tulevik terviklikuks ketiks, kui maailm oli tunnistanud ennenägematut vägivalda? Esimene maailmasõda tekitas meeltesegadust nii nende hulgas, kes sõjasündmusi tunnistasid ja/või neist osa võtsid, kui ka nende seas, kes neid vaid kaudselt kogesid. Semper teenis alates 1916. aastast tsaariarmees ja sai 1917 lipniku auastme. Kõige kurnavam oli Semperile 1916. aasta aprillist kuni detsembrini Tambovi kasarmus veedetud õppus, rindele teda ei saadetud. (Siirak 1969: 50-52) 
Semperi varases loomingus leidub viiteid sõjale novellis „Püha umbrohi” (1918), milles peategelane, Peterburi üliõpilane Alla taaskohtub rindel viibinud peigmehega. „Punapõsksest ohvitserist” on sõjas „saanud unine olevus” ja Allale on vastik mehe „tardunud üleolek” (Semper 1918: 22). Bergsonlikus mõttes toob sõda nähtavale inimese parasiitmina, tarretades sisemise voo, energia ja elurütmi ning tehes sõjakogemusega inimese kunstlikuks ja uniseks. Siiski on selles novellis Semperi sõjakriitika ning sõja lagundavale iseloomule osutamine veel hillitsetud. Sõja katkestav olemus nihkub esiplaanile hoopis tema luules. Semperi luulekogud „Jäljed liival” (1919) ning „Maa ja mereveersed rytmid” (1922) lähtuvad tema sõja- või selle järgsest kogemusest ning need on tajutavalt sõjavastased (Hennoste 2016: 343-345). Nendes kujutab Semper sõjaga seotud äärmuslikku jõhkrust, haigusi ja invaliidistumist. Otsene viide moonutatud nägudega ja vigastele inimestele leidub luuletuses „Mao rõngan”: „Näha teisi sante liikmeid väristavat / Teisi kelle käsi korvab kynt / Teisi karkudega ringi komberdavat / Teisi kelle nägu yles kynt" (Semper 1922: 20). Semper kujutab siin meesvaatepunktist ebaloomulikku ja sõjas laastatud mehekeha.

Kõige mitmetahulisem on sõjakujutus kogu „Ellinor” (1927) novellides „Astrid”, „Niidukressid” ja „Entsian” (vt Karelson 2015: 274-275; Kirikal 2017: 419). Neis kirjeldatakse naistegelase vaatepunktist seda, kuidas sõda sunnib meestegelasi kahte äärmusse. Novellis „Astrid” kujutatakse aktiivses sõjategevuses osalevaid mehi, keda iseloomustavad vägivalla õigustus ja julmus. Avantüürikihuga minategelane Ellinor, kes oma energilise ja positiivse ellusuhtumisega kehastab harmoonilisust (Kirikal 2017), on oma ajutisest elukohast mööduvatele sõduritele halastajaõeks. Ta kirjeldab tallu sattunud ohvitseri kommet pidevalt midagi ebameeldivat nuusutada ning korjata näiteks mädanevaid õunu: „Hiljemini aias tõstis üles mädand õuna, hoidis seda kaua käes. [---] ta kaapis vaid veidi niisket sammalt puukoorelt ja pistis selle nina alla. Kui nägi, et ma teadlik olin ta toiminguist, naeratas vähe: // - Teile ei meeldi? Teile ei meeldi sügis, mädanevad lehed, seened?” (Semper 1927b: 33) Ohvitser ei „põland lahinguväljade lõhna teisel, kolmandal päeval". Sellega loob ohvitseri kuju mõtteseose sõja, lagunevate surnute leha ning riknemise ja mädanemise vahele. Kuid see võib olla ka allusioon vängelõhnalisele sinepigaasile, millest sai koos gaasimaskiga Esimese maailmasõja hirmuäratav sümbol (Undusk 2015: 197-204). Ohvitseri veidrad nuuskimistavad rõhutavad igal juhul humaansuse kadu: massihävitusrelvast või laipadest eralduva ilge haisu sarnased lehad tekitavad mehes nostalgiat. Terviku elava, terve inimkeha - lagunemine sõjas langemise tõttu on ohvitseri ninale nauditav, mis näitab sõja absurdsust.

Semper kujutab ka sõjast muserdatud meestegelasi. Novellis „Entsian” jutustab Ellinor sõjajärgsest ajast „hellema” hingega poeedi Siemseni elus. Ellinor kirjeldab luuletaja žeste, riideid, pilku, liigutusi sõjatemaatika kaudu: „Ta püksiriie on see vastik sõjaaegne sinkjashall kalev [---] Ta pedaali surumine rasketaldsete saabastega, ta põlvini ulatuvad sukad kõnelevad marssimisest sõdurina ühest külast teise [---]." (Semper 1927b: 101) Pidevalt ärritunud Siemsen hüpleb eri teemade ja emotsioonide vahel. Peategelase mõista andmine, et „sõda õpetas univormi ja vormi” (Semper 1927b: 106), samuti kaastegelaste vihjed poeedi hullumeelsusele seovad Siemseni vähemasti osaliselt sõja raputavate järelmõjudega. Siemseni habrast, kergelt 
ärrituvat olekut ja üksildast kuju võib seostada mürsušokiga. Selle mõiste võttis 1915. aastal kasutusele füüsik ja psühholoog Charles Samuel Myers, viidates sellega tegevsõdurite massilisele vaimsele ja füüsilisele häiritusele (Johnson 2017: 7). Ühtlasi puudutas mürsušokk, mille sümptomiteks olid une- ja tajuhäired ning hallutsinatsioonid, ka tsiviilisikuid ja rindekogemuseta sõdureid (Tate 2013: 21, 30). See nähtus ja mõiste teke päästis valla ulatusliku debati keha, psüühika ja trauma üle (Armstrong 2005: 20). Trudi Tate on osutanud mürsušoki kui teatava neuroosi n-ö diskursiivsele mõjule: see levib ka ringlevate traumeerivate lugude kaudu. Mürsušokki on uuritud nn kirjanduslikus kõrgmodernismis, eriti Virginia Woolfi romaanis „Proua Dalloway” (1925), aga ka näiteks H. D. (Hilda Doolittle’i) teoses „Kora ja Ka” (1934). (Tate 2013: 28-29)

Mürsušokiga seostub ka novelli „Niidukressid” ainus meestegelane, lonkav ja üksildane sõjaveteran Mehik, kelles on midagi „pehmet, mahedat” ja keda ta naine alavääristab ning minategelane kirjeldab kui tähelepandamatut (Semper 1927b: 66-67). Mehikut on küll kujutatud naeruväärselt iseloomutu ja õnnetuna, selleks et võimendada tema naise Liibeoni emantsipeeritust ja lesbilisust (Kirikal 2017: 427-429), aga mehe habras kuju näib tulenevat ka sõja traditsioonilist maskuliinsust purustavast jõust. „Ta elas üleval ärklitoas, kust teda vaid õhtuti kuulda oli: mängis omaette viiulit, tundide-pikkust viisi, millel polnud algust, otsa ega selgroogu" (Semper 1927b: 65). Meloodia ebamäärasus viitab võimetusele eesmärgipäraselt tegutseda ning keskendumisvõime kaole nii sõja kui ka soosuhete ümberkujunemise tõttu. Mehik on osaliselt muutunud naiselikuks ja pärast õhtusööki mängib ta väidetavalt iseendaga malet, millega seoses meenub minategelasele see, et Mehik, „näidates vigasele jalale, õhkas oma saatust ning mainis malesoldati oma paremaks: malemängus ei olla tegemist vahepäälsetega, vaid ikka kas elusate või surnutega" (Semper 1927b: 67). Mehik selgitab end niisiis vahepealsena: ta pole ei üks (elus) ega teine (surnud) ja see vihjab tema soolise identiteedi ebakindlusele.

Pisut teistmoodi tuleb sõda esile romaanis „Armukadedus”. Selle peategelasi Kristat ja Ennu on mõjutanud erinevad sõjad. Krista oli Vene kodusõja päevil halastajaõde, minevikumälestused käivad tal tihedalt kannul (Semper 1934: 79). Enn aga võttis koos sõbraga osa rindetegevusest. Samas sedastavad nad sõja mõju erakordselt põgusalt. Ennu rängim kogemus oli sõber Eevalti kaotamine: „Aga siis hiljem, ühel küünlakuu pakasel päeval, tuli mul astuda sinna [Eevalti ja tema õe - M. K.] majja, kaenlas Eevalti verine lambanahka kasukas ja ta pruunid vildikud. [---] Ent polnud aeg lohutamiseks, pidin tagasi ruttama rindele." (Semper 1934: 58-59) Minevikku meenutades mõtleb ta sõjale vaid viivuks, aga sellest on tajuda, kuivõrd lõhkuv ja arulage oli tema jaoks sõda, millest tuleneb ka ehk tema intensiivsem vajadus terviklike ja orgaaniliste inimsuhete ja -kehade järele.

"Armukadeduse” tegelaste kujutusi kannab soov unustada haavatud ja surevad mehekehad. Näiteks ei tea me midagi Ennu keha kohta: nahka, kõnnakut, juukseid jm. Kui Enn kirjeldab Krista ihu detailselt ja Krista räägib oma kehast meeleldi, siis kumbki ei kommenteeri Ennu (sõja vormitud, fragmentaarset?) füüsist. Krista mainib, et Ennu juures on ihaldusväärne tema enesekindlus ja uhkus (Semper 1934: 80). Enn rõhutab oma vaatlusoskust, juhtimistahet ja üleolekut (Semper 1934: 11). 
Need on aga iseloomuomadused, mida on raske seostada Ennu kehaga. Rohkem tuleb maskuliinse keha tajumine välja kohtades, kus Enn võrdleb end teiste meestegelastega. Enn sedastab oma sõbra Raudhamba kohta: „[---] oli päris kadestatav ta terve eluinstinkt, ta jõukultus [---]" (Semper 1934: 22, vt ka: 50-51). Võib oletada, et kui Enn osutab Raudhamba jõule või Lingi „atleetsele kehaehitusele” (Semper 1934: 22), on ta ise nende vastandina vähem sportlik ja vitaalne, vähem terve/terviklik, mis viib tagasi rindekogemuseni. Enn väljendab „Armukadeduses” maskuliinsust mitte keha, vaid vastava käitumise ja väärtuste kaudu. Mehele sobivale käitumisele viidatakse seoses kõnemaneeriga: poeet Elfenbeini kunstlik kõnelemisviis ning hoolitsetud välimus ärritab traditsiooniliselt maskuliinseid mehi (Semper 1934: 13-14, 22). Ka on mittemehelikud teatud teemad, mida halvustatakse (nt armumine, kapriisid, tujud) (Kirikal 2016: 28, 30). Seega on tavapärase mehelikkuse alalhoiuks vaja kontrolli selle üle, kuidas ja mida rääkida ning kuidas käituda. Kuna mehe keha on teoses tabu, siis Enn justkui tasakaalustaks seda sellega, et kuvab oma kehalikustatud ideaalid naistegelastesse ja erakordsesse vorminõudlikkusse.

\section{Puhas keel ja veatu keha}

Semperi esteetika on seotud vormiga. Kunst avaldub Semperi meelest siis, kui kogemust väljendatakse teatavas vormis (Semper 1919: 7). Kirjanduses kujuneb spetsiifiline vorm muuhulgas keelekasutuse kaudu. Kui vaadelda keele- ja vormiküsimust Bergsoni ideede taustal, siis tuleb esmalt mõista tema ajakäsitust. Bergsoni järgi on kaks erinevat aega. Esiteks, kellaga mõõdetav aeg on ruumiline ja jagatav. Teiseks, isiklik, tõeline aeg on mõõtmatu heterogeenne kulg, mida inimene kogeb oma teadvuses. (Bergson 2006: 73-74) Just seda mõõtmatut üritas modernistlik kirjandus uuenduslikult ehk teadvuse voolu abil tabada. Teadvuse voolu mõiste pärineb psühholoog William Jamesilt, kes uskus nagu Bergsongi, et subjektiivne elu kogemine on voolav, igasuguste formaalsete katkestusteta (Nicholls 2009 [1995]: 200). Modernistlikud autorid tundsid huvi aja ja olemise vastu ning eelistasid subjektiivseid tajumusi, olemist ennast, mitte olemise stiliseeritud representatsioone (Gillies 2003: 103). Paljude tollaste kirjanike (Virginia Woolfi, Robert Musili, Marcel Prousti, A. H. Tammsaare) loomingus esineb selge vastandumine homogeensele ruumiliselt määratud ajatajule (Hinrikus 2013: 38). „Armukadeduses” tuleb see esile armumist ning suudlusi või embusi kujutavates stseenides, kui Ennu ajataju kaob ning ruum muutub tema sõnul totraks ja tühjaks (Semper 1934: 91, 95). Bergsoni meelest ei saa kestust (kas või armumisel kogetavat) tõeliselt jäädvustada, sest kirjutamine tükeldab kogemuse. Ta käsitleb keelt n-ö alamana võrreldes kestuse ja tõelise intuitiivse olemisega, väites, et keel langetab tunded ja ideed igapäevasusse. Keel asetab - võibolla väga rikkalikult - mõtted üksteise kõrvale, aga ei sulata neid tervikuks. (Bergson 2006: 14, 119)

Kui kellegi võimuses on süstida oma keelega tundmustesse „algset ja elusat individuaalsust”, siis on see romaanikirjanik (Bergson 2006: 119). Efektiivne keel on sugestiivne, edastades hoogsalt seda, mida justkui edasi anda ei saaks. Keele ja 
vormi sulandumine ei tähenda niisiis segase sisu väljendamist segases vormis, vaid sellise struktuuri leidmist, mis on kooskõlas läbielamistega, kuid ei ole veel vormitus (Semper 1910/11: 463). See tähendab omakorda, et Bergson ei mõjutanud modernismi mitte ainult oma uuendusliku ajakäsitusega, vaid ka keele rolli reformimisega (Posman 2013: 213). Ka Semper rõhutab Bergsoni keeleideid: läbielamise analüüs on alati tükiline ning romaanikirjanik peab need tükid osavalt ühendama, nii et saadud kujutis oleks afektiivselt mõjus ja peaaegu põhjatu (Semper 1915a: 27). Nii on oskuslik kirjanik see, kes suudab kestust väljendada sisendusjõulise keelekasutusega. Romaanikirjaniku sobiv - tavapärasest erinev, tardunud sõnu vältiv - keel päästab valla tahkestunud muljed ja paljastab pidevalt muutuva tunde (Bergson 2006: 95).

Seisukohta, et keel kujutab tõelust vaid siis, kui seda kasutatakse efektiivselt, on nimetatud modernistliku kirjanduse keelehügieeniks (Bell 2003: 70). Mitmed modernistid (Ezra Pound, T. S. Eliot) uskusid, et kui kellegi keelekasutus on lopergune ja ebatäpne, siis peegeldab see nii emotsionaalselt kui ka intellektuaalselt keelekasutaja reaalsust. Sellist „hügieenilist” keelevaadet jagas ka Friedebert Tuglas (Hinrikus 2020: 175-191). Kuidas seostub Bergsoni keele efektiivsuse ja sugestiivsuse unelm ning keelehügieen tollase eesti kultuuriga ja Semperi romaaniga „Armukadedus"?

„Armukadeduse” sissejuhatuses sõnastab Enn, kellele kuulub ka autori sümpaatia, oma hoiaku ümbritseva ja mälestuste suhtes. Sellest kumab soov jõuda mingisuguse tõeni ehk tabada mingit tervikut. Retseptsiooni järgi sõnastab Enn oma mälestuse erakordselt täpses keeles. Tuglas on rõhutanud romaani stiili harukordset läbimõeldust ja selgust (2004 [1935]: 298). Valmar Adamsi arvates on teos justkui „inseneri tsirkliga joonistet” (1934: 464). „Armukadeduse” läbimõelduse ja lihtsuse seob Tuglas autori vaevarikka töö ning sisu eesmärgiks seadmisega (2004 [1935]: 298). Adamsi sõnul on stiil teose tugevus: ta kiidab selget kujukat keelt, üldiselt sirgjoonelist jutustust ning tõika, et puuduvad ebaselged laused (1934: 464). Näib, et viimistletud stiil tähendab nende kriitikute ilmapildis igasuguse keelelise jäägi (tühilausete) puudumist, lõikude järjekindlat ja pikaaegset toimetamist ning n-ö puhast lõpptulemust.

XX sajandi alguse eesti kultuuritekstid osutavad keelekasutuse seostele isikuomadustega. Seda väitis ka Semper (1971: 163), kui ta 1936. aastal Tuglase stiili kohta arvas, et see on kõike muud kui „vedel, ilmetu ja räpane”: „Nagu käekiri kõneleb inimese loomusest, nõnda ka tema stiil. Stiilitus pole siis ilupuuduse, vaid karakteripuuduse küsimus." (Semper 1971: 164) Seega kehv, ühekülgne ja loid keel kõneleb inimese napist isikupärast. Seda hoiakut peab Semper silmas oma tegelaskujusid luues. Negatiivsetel ja isikupäratutel tegelastel on kalduvus teha ortograafiavigu ning omada nõrgana mõjuvat käekirja (nt Evi „Hiina ketis”, vt Semper 1918: 105) ning kirjatähed on sooliselt märgistatud: lesbilisel proua Liibeonil novellist „Niidukressid" on mehelik käekiri (Semper 1927b: 58-59). Semperi loomes segunevad niimoodi sõnavalik, üldine stiil, käekiri, karakter ja keha.

Adams valis Semperi stiili kiitmiseks sirkli metafoori. Sellega viitab ta pedantsele täpsusele: sirkliga saab joonestada laitmatuid sõõre, kus pole ebakohti ega katkeid. Semperi keelekasutus on seega korrektseks lihvitud, korrapärane. Selline stiil ei ole 
seotud üksnes (modernismi) üldiste ilunõuete ning eesti kultuuris tollal aktuaalse keeleuuendusega, vaid haakub ka Semperi futurismihuviga. Semperit peetakse futurismi esmaseks vahendajaks eesti kultuuris. Kuulanud tudengina 1914. aastal Peterburis esinemas itaalia futuristi Filippo Tomasso Marinettit, pidas ta Eestis temast kaks ettekannet. (Hennoste 2016: 324; Siirak 1969: 38) Futurismi filosoofilist alust on mõjutanud Friedrich Nietzsche ja Henri Bergson (Nicholls 2009: 82-83). On omamoodi paradoksaalne, et organitsismist ideid ammutanud Bergsonist sai eeskuju futuristidele, kes esiteks ülistasid kõike mehhaanilist ning teiseks suhtusid põlgusega mällu, mäletamisse. Viimane on ju võtmeline Bergsoni minakäsituses, sest ilma oma eelmiste hetkede tajuta ei suuda mina olla terviklik (Nicholls 2009: 84, 334). Tõik, et Semper oli huvitatud nii futurismist kui ka organitsismist ning sidus neid oma teostes, annab märku Semperi loomingu komplekssusest ja vastuoludest. Selline vastuolude koondumine oli tollasele Eesti kultuurile tunnuslik: alates NoorEestist on kultuuritekstides võimalik täheldada eri voolude keerukat ja ebajärjekindlat põimumist ning esteetilise dominandi määramine on raske (Kivimäe 2008: 23).

Semper toob futurismi ühe ettekirjutusena esile „kõvera joone, spiraalse vihkamise, õgujoone ja tundli armastuse" (Semper 1919: 46). Selle krüptilise lause kaasab Semper ositi oma rangelt orgaanilistesse stiili n õ u e te s s e ja keha i d e a a li d e s s e, st oma loomingu sellesse kihti, mis teeb ettekirjutusi. Õgu- ehk sirgjoon tähistab nii stilistilist printsiipi (sisu peab liikuma eesmärgipäraselt, arusaadavalt) kui ka tegelaste vaimseid (vastuoksuste puudumine, n-ö sirgjooneline käitumine ja mõtlemine) ja kehaideaale (sirged saledad naisekehad, kehaeritiste vähesus). Tasub tähele panna, et see sirgjoon on alati orgaaniline, ehkki esmapilgul võib see kooslus tunduda vastuolulisena. Ühtlasi haakub sirgjoon stereotüüpsetes kujutelmades mehelikkuse ning kõverjoon naiselikkusega, seda juba alates antiikkultuurist (Cranny-Francis jt 2003: 1-2). Kõverjoone ja mügarlikkusega seostuvad tihti nahamoodustised, mis piinavad Semperi antipaatseid tegelasi. Näiteks kuulujutuhimuline toimetaja Uhak ajab küll hoolega habet, kuid mulje on siiski säärane, „,nagu oleks mõni karvatutt kuhugi jäänud tolknema" (Semper 1934: 26). See mulje tekib põse alumises osas paiknevast käsnast, mida Uhak vabal silmapilgul keerutab. Samasugune käsn laiutab lesbilise Liibeoni näos novellis „Niidukressid”. Loomulikust sirgjoonest eenduvad ja tolknevad moodustised - nii kehal kui ka stiilis - on Semperi perfektsionistlikus maailmas lubamatud.

Ka kirjandusliku keelekasutuse kohta väidab Semper, et hea tekst sünnib piiride tõmbamisest, kitsendusest (st tolknematusest), autori võimest oma musklite-närvidega elada tegelastesse sisse, lihtsast-puhtast väljendusest ning ühtsest ideest, mida väljendavad sisu ja vorm koos (Semper 1931: 419-420). Sisu ja vormi sulandumise nõue kõneleb orgaanilisusest. Loomingulise protsessi kehalises tajumises (musklitenärvidega sisseelamine) on Semper usutavasti inspiratsiooni leidnud Nietzschelt, kes seob loomingulise keskpärasuse autori „sisikondliku loidusega” ning peab vaimutööd ainevahetuse vormiks (Nietzsche 1996: 36-37). Semper - äärmusliku esteedina - on nietzschelikult loova sisikonna küll asendanud kehaosadega, mis midagi ei erita. Mõlema väited viitavad vaimse töö totaalsusele. Semperi kitsenduse ja lihtsa-puhta väljenduse nõue rõhutab võimalikult vähest keelejääki. Need on kõik 
ebavajalikud paigad tekstis, mis on Semperi sõnul kiirustamise, vähese korrigeerimise tulemus, teisisõnu on keelejääk kirjelduste ja kujutuste ballast, mis ei aita kaasa kunstilise terviku saavutamisele (Semper 1931: 420-421).

Modernistide jäägi- ja jäätmefoobia hea näide on populaarne söömistehnika ja -ideoloogia, mille rajas XX sajandi alguses Horace Fletcher (Armstrong 1998: 43, 62). Selle järgi oli oluline närida aeglaselt, et ergutada seedeprotsessi ja kõhnuda. Toitu tuli mäluda kuni suus lahustumiseni: juba suhu pistetud toit muutus jäägiks, mis tuli põhjalikult läbi närida, et selle seedimine ei koormaks keha, annaks energiat ja vormiks ideaalse väljaheite. See tehnika sihtis niisiis maksimaalset kasu ja minimaalset jääki. (Armstrong 1998: 43) Semperi looming on lahustumiseni närimise, jäägipõlguse hea näide. „Armukadeduses” on stseen, kus armukolmnurka sattunud Enn, Krista ja Viktor koos einestavad. Enn ei jäta põlgusega märkimata, kuidas Viktori „harjumuseks oli lobisema hakata just siis, kui põsk punnis oli” (Semper 1934: 177). Eelkõige šokeerib Ennu hetk, mil Viktor, „kuigi salvrätiku varjus, näppudega hammaste vahelt hakkas härjalihakiude välja sikutama” (Semper 1934: 177). Jägid poolmälutud söök ning toidutükid hammaste vahel - mõjuvad Ennule võikalt ning Viktori negatiivne kehalikustamine aitab tal saada tagasi enesekindlust rivaaliga koos viibides.

Sarnaselt toimivad Semperi tekstides sekreedid: ebameeldivad tegelased on sageli tatised, positiivsed tegelased aga nohuvabad. Näiteks satiirilises novellis „Kadunud poeg” kogust „Sillatalad” teeb korrumpeerunud ja kogukas ettevõtja Talapuu järgmist: „Talapuu pühkis oma ärasõidu erutuse laia valgesse taskurätiku, millega mahajääjaile sadamas oli lehvitanud, ja nuuskas veel kord kõvasti” (Semper 1927c: 51). Samamoodi nuuskab punapäine tedretähniline Remmelgas, konservatiivne ja antipaatselt kujutatud pastor „Armukadeduses” (Semper 1934: 138).

Kõige radikaalsem jäägi-/sekreedikujutus - nii Semperi loomes kui ka kogu tollases eesti kirjanduses - leidub „Armukadeduse” lõpposas, mil Enn aitab Kristat puhastada pärast nurisünnitust. Krista on kandnud eelmises suhtes umbes nelja kuu eest eostatud last, tal tekib verejooks ja rasedus katkeb. Nurisünnituse järgsete toimingute meenutamine täidab Ennu „mõnesuguse läägusega” (Semper 1934: 325). Kurnatud ja äsja lapse kaotanud, vigastatud ja verine naisekeha toob kaasa meespeategelase pideva viitamise häbile, piinlikkusele, tülgastusele, iiveldusele, aga mitte kaastundele. Sedastagem, et positiivne keha tähendab Semperi loomingus eelkõige estetiseeritud, kuiva ja sirgjoonelist keha, mis ei aja endast midagi välja. Ideaalne keha ei moodustu kunstlikult kombineeritud osadest, vaid on üdini terviklik (ja terve). Sellisena kujutab Semper oma atraktiivseid eeterlikke naistegelasi, kes on tihti seotud modernse tantsuga.

\section{Ideaalne naisekeha kui tervik: tantsijanna kultus}

Modernne tants sündis Saksamaal ja Ameerika Ühendriikides Esimese maailmasõja eel, kuid selle hiilgeaeg oli sõdadevahelisel perioodil (Manning, Benson 1986: 30). Moodsa tantsu teerajaja oli ameeriklane Isadora Duncan (1877-1927). Eestis 
kujundas tollast modernset tantsu Ella Ilbak (1895-1997). Tantsu hinnati XX sajandi alguses kõrgelt esiteks sõjajärgsete vägivallast tülpinud ja skeptiliste meeleolude tõttu, mis ajendasid erisuguseid harmooniaotsinguid, ning teiseks üldiste tendentside pärast ajastu esteetilistes eelistustes. Nietzschelik antiikkultuurist lähtuv dionüüsiline maailmanägemine, Bergsoni igavene voogamine ja edasiliikumine ning eri kehatehnikate austus kõneleb perioodile omasest rütmi- ja liikumiskesksusest (Undusk 2009: 644).

Tollase tantsuvormi uudsus selgub võrdlusest varasemate tavadega. XIX sajandil oli Euroopa ooperimajades etendatud traditsioonilisi narratiivseid ballette. 1870.1900. aastatel tekkisid aga innovaatilised tantsutehnikad: Kate Vaughani nn seelikutantsud Londonis, kankaan Pariisis ning vabatantsud, näiteks Loie Fulleri tehniline serpentiintants, mis inspireeris Stéphane Mallarméd. (Jones 2009: 237, 239) Enim kuulsust saavutas Duncan, kelle esinemised Saksamaal XX sajandi esimesel kümnendil vastandusid harjumuspärasele tantsuvormile ehk danse décole'ile kui puhtale akadeemilisele balletile (Jones 2013: 5). Vabatants erines balletist tugeva individualiseerituse ja ekspressiivsuse poolest: tantsija mõtles ise välja koreograafia ning esitas oma tantsud üksinda. See tähendas ka tantsija suuremat autonoomsust ning omapära. (Jones 2009: 240, 242) Semperi (1919: 84-85) hinnangul on klassikaline ballett tehnika, mitte läbielamine, ja kuna talle on kunstis oluline tundmus ja tõlgendus - mitte akrobaatika ja dekoratiivsus -, siis eelistab ta ilmselgelt vabatantsu.

Vabatantsu ideestik toetus antiikkreeka kehaideaalidele (Carden-Coyne 2009: 266), mistõttu on vabatantsu nimetatud ka klassikaliseks kreeka tantsuks. XIX sajandi lõpus ja XX sajandi alguses elavnes Vana-Kreeka kultuuri ihalus mitme teguri koostoimel. Esiteks toitis huvi kreekalike kehaideaalide vastu olümpiamängude taaselustumine 1896. aastal (Jones 2013: 52). Teiseks panustas Vana-Kreeka kultuuri taasavastamisse Nietzsche eelkõige oma „Tragöödia sünniga” („Die Geburt der Tragödie aus dem Geiste der Musik”, 1872). See oli koos teosega „Nõnda kõneles Zarathustra” („Also sprach Zarathustra”, 1883-1891) otsene inspiratsiooniallikas Isadora Duncanile, kes sulatas oma loomes niisiis tantsu ja filosoofia (LaMothe 2005: 244, 247). Kolmandaks levis XIX sajandi lópu ja XX sajandi alguse lääne kultuuris üldine eksootikahuvi ja idamaisuse ning Vana-Kreeka (aga ka Vana-Rooma, Vana-Egiptuse, Bütsantsi) seostamine sensuaalsusega (Kermode 2004 [1957]: 67; Lyytikäinen jt 2020). ${ }^{4}$ Tänu nendele tendentsidele hakati ka antiikmüütidele rohkem tähelepanu pöörama ja neid modifitseerima. Semper ja Tuglas töötlesid näiteks Pygmalioni ja Narkissose müüte (vt Kirikal 2020). Semperit huvitas müütide nietzschelik tähendus. Tema hinnangul on Nietzsche arutlused Kreeka tragöödiate apolloonilisest (Semperil „selgumisjärk”) ja dionüüsilisest aspektist (Semperil „joovastus") konkreetselt seotud moodsa tantsu ekspressiivsusega: tantsus ühinevad ideaalis mõlemad poolused (Semper 1919: 24, 100). Nietzscheliku mõttetraditsiooni järgi ongi moodsa kultuuri suurim ebakoht sidemete katkemine antiiktragöödiate

\footnotetext{
${ }^{3}$ „Nõnda kõneles Zarathustra” Johannes Palla tõlkele (1932) kirjutas järelsõna Semper.

${ }^{4}$ Vana-Kreeka ja Vana-Egiptuse kultuurist, sensuaalsusest ja tantsust inspireerumist võib märgata ka eesti dekadentlikus ja/või modernses kunstis, näiteks Nikolai Triigi, August Roosilehe, Gori, Eduard Viiralti, Oskar Kallise jt töödes (vt Hinrikus jt 2017).
} 
sensuaalsuse, intuitsiooni ja tõega, st dionüüsilisusega (Childs 2008 [2000]: 65-66). Siin võib näha seost Bergsoni filosoofia intuitsiooni, süvamina ja kestusega. Samas tasub meeles pidada, et dionüüsiline ja apollooniline kuuluvad orgaaniliselt kokku (Jones 2013: 48). Disharmooniat tekitab niisiis ühe domineerimine teise üle.

Sellist hellenistlikku vaimu väljendaski Duncan (ja tema järgijad, sh Ilbak), kes ammutas ideid peale Nietzsche ka Vana-Kreeka dünaamilistest vaasimaalidest ja skulptuuridest (Carden-Coyne 2009: 282). Skulptuur (eelkõige apollooniline) ja tants (eelkõige dionüüsiline) kuuluvad kokku ka Semperi „Armukadeduses”: „Kõigist kunstidest mõistis Krista kõige enam skulptuuri ja tantsukunsti. Ta kahetses, et ta päris noorena polnud viimast õppima hakanud." (Semper 1934: 162) Krista on sellest rakursist duncanlik tegelane.

Duncanit võibki pidada Semperi tantsijanna-kujutuse peamiseks eeskujuks. Semper nägi tema etendust Peterburis 1913. aastal ja see jättis temasse sügava jälje (Semper 1919: 99). Duncan kehastas Semperi (ja varem nooreestlaste) jaoks ülimat tundlikkust ja täielikku individuaalsust. Tema kunst oli jäljendamatu ja selles väljendus Semperile ideaaliks olnud ainulaadne kirgliku tundeelu ning nõtke kehaga naine (Semper 1919: 84). Duncani stiili mõju Semperile johtub ka selle orgaanilisusest ehk esituse ja esitaja sulamisest tervikuks. Seda orgaanilisust võimendab tantsijate endi ja ka kriitikute arusaam vabatantsust kui loodusnähtusest, mis tekib iseeneslikult, seestpoolt. Duncan kirjeldas tantsimist kui rütmilist ühtsust, mis liigub läbi kogu looduse, kui ookeani lainetust. (LaMothe 2005: 253) Semper nägi Duncani lainetustes spontaansust, joovastust, kuid lisas, et need on tantsija isikus põimunud intellektiga (Semper 1919: 100). Võib-olla just lainja ja loodusliku Duncani mõjul võrdles Semper (1929: 1307) Ilbaku mustreid madudega (käsivarte ussiline, st lainetav liikumine) ja leidis, et ta on „nagu taim juurtega maas kinni”. Ka Ilbak ise mõtestas oma tegevust orgaanilisena, nimetades oma sooloetenduste kuulsaima numbri „Leegiks”. Tantsu naturaalsust rõhutas ka Loie Fuller - tema ühe tantsu nimi oli „Leegi tants" -, sõnades, et ta ei tea, kuidas ta tantsib, see on vaid intuitsioon ja instinkt (Fuller 1913: 59, 66).

Paljud tollased mõtlejad tegelesid niisiis vähem või rohkem tantsu selgitamisega, teiste hulgas ka Bergson. Ta toob tantsu arutellu pisut teistsuguse mõõtme:

Nurgelistes liigutustes pole nõtkust, sest igaüks neist on eneseküllane ega kuuluta ette järgnevaid. [---] Kergete liigutuste tajumine sulandub siin naudinguks, kus aja kulg teataval moel peatatakse ja kus tulevikku olevikus hoitakse. Kolmas element sekkub siis, kui nõtked liigutused kuuletuvad rütmile ja kui muusika neid saadab. Sest rütm ja taktimõõt võimaldavad meil veel paremini kunstniku liikumist ette näha ning tekitavad meis mulje, et me oleme nüüd selle isandad. Kuna me peaaegu aimame ette poosi, mille tantsija võtab, siis näib ta meile kuuletuvat [---] Tõsi on see, et kõiges väga nõtkes ei näe me ainult kergust, mis on liikumise märk, vaid see näib osutavat ka võimalikule liikumisele meie poole, võimelikule või isegi sündivale sümpaatiale. See liikuv sümpaatia, mis on alati ennast andmas, ongi kõrgema nõtkuse olemus. (Bergson 2006: 15-16) 
Bergson põimib tantsija naiselikustatud kuju promiskuiteediga, väites, et tantsu jälgimine pakub (mees)vaatajale võimutunnet ning lootust, et anduv tantsijanna liigub vaataja poole. Säärane pilgule allutatud tantsijanna esineb ka Semperi luuletuses „Tantsjanna” (1915), mille viimastes ridades kujutab lüüriline mina tantsijannast väljuvat lihalikku signaali: „Näol hõõguma löönud on silmi söed: / võta mind, / võta mind! / Kires väänlevad käed nagu paluvad õed: / murra mind, / murra mind!" (Semper 1917: 52) Siin on rõhu all tantsija joovastus ja erootilisus, mitte sensuaalsuse põimumine intellektuaalsusega, mida Semper on hiljem enam alla jooninud: Semperi noorusloome on tuntavalt erootilisem kui tema hilisemad kirjutised. Bergsonismiga seostub see luuletus veel teisegi nurga alt. Tants on siin nimelt helmestik, põiming: „Kas ehk tantsu helmestikuks oled tiin’? [---] O neid looklevaid, väänlevaid, / põimuvaid, haaramata käänlevaid / käte ja jalgade radu!" (Semper 1917: 50-51) Selles tuleb vahest kõige ehedamalt esile noore Semperi maskuliinsest vaatenurgast konstrueeritud terviklik ja orgaaniline naisekuju - dionüüsilises joovastuses, tajutavalt himur ja terviklikult ketjas tantsijanna. Merele, lainetele, valgele marmorile ja jumalaile viitamine lubab näha Semperi tantsijatari prototüübina Isadora Duncanit.

Helmestiku, tantsu ja antiikkultuuriga haakub ka „Armukadeduse” Krista, kelle terviklikkus tuleb esile vastanduses romaani teise naistegelase Herma pisut kohmaka kehaga (Semper 1934: 61-62). Krista on graatsiline, arendades oma nõtkust treeningu, karastuse ja võietega (Semper 1934: 161). Naise hommikused rutiinid ei ole aga seotud kunstiga. Kunst ja treening on Kristale eri asjad ning tantsimist rasvapõletuse eesmärgil Krista ei sallinud: „Põrmugi ta ei tahtnud saada nende seltskonnadaamide sarnaseks, kes harrastasid „plastikat”, pildudes ja väänates õilsalt oma liikmeid, et ainult rasvakorda naha all õhendada" (Semper 1934: 162). Krista austab tantsu eneseväljendusliku kunstina, mitte treeninguna. Võimalik, et Krista tahab vastanduda harrastustantsijate massile, et säilitada oma huvitavus ja unikaalsus. Samal ajal soovib ta siiski Ennule tõestada, et ta on "naiselik” ja erootiline: neid omadusi seostati tollases lääne kultuuris just tantsijanna nõtke figuuriga (CardenCoyne 2009: 273, 301).

Ent Krista pelgalt räägib tantsimisest, mitte ei tantsi. „Armukadedusest” ei leia õieti ühtki konkreetset tantsu - ei vabatantsu, seltskonnatantsu ega metsikut ja instinktiivset tantsu, mille kuulsaim kujutus on vast Annalt D. H. Lawrence'i teoses „Vikerkaar” („The Rainbow”, 1915). Isegi peol, kus Enn ja Krista kohtuvad ja teised külalised tantsivad, nad seda ei tee. See annab romaanile nukra alatooni, sest tantsu kui vabaduse, loovuse, individuaalsuse ja terviklikkuse sümboliga ei tegelda.

\section{Kokkuvõtteks}

Orgaanilisuse ja terviklikkuse esteetika raamistab Semperi kuni Teise maailmasõjani kirjutatud kriitikat ja ilukirjandust: orgaanilisuse/terviklikkuse kaudu mõtestab ta kirjandussituatsiooni ning just nende mõistetega selgitab ta väärtusliku ja vähemväärtusliku kirjanduse erinevust. Sellise taustsüsteemi loob ta saksa romantismi orgaanilisuse austuse ja Henri Bergsoni filosoofia kaudu. Viimane on Semperi üks 
tähtsamaid inspiratsiooniallikaid. Bergsoni mõtestatud seesmise survena paisuv eluhoog, intuitiivsus ja kestus on Semperi tekstides sage ja kõrgelt hinnatud teema. Ühtlasi ajendab bergsonlik kreedo Semperit kasutama kestust tähistavat ketimotiivi. Tervikuks põimimise püüdlust on põhjustanud ka Esimene maailmasõda ja selle järelmõjud, sh traumeerivate nähtuste diskursiivne ringlemine, muutes Semperi nn ketitaotluse ühiskondlikult tundlikumaks. Sõja vormitud kehad ning nendega seonduv fragmendihirm leiavad tee pea kõikidesse Semperi ilukirjanduslikesse tekstidesse.

Mainitud tegurite koostoimel seadis Semper endale ajastuomase sihi kuulutada ja kujutada midagi orgaanilist, terviklikku, tõelist. Need omadused saavad nähtavaks eelkõige kaunis, nõtkes, tantsivas naisekehas ehk loodusnähtuses, milles sisu ja vorm on harmoonilises põimingus: väline (hurmav keha) ja sisemine (selginenud vaim) moodustavad piiritletud terviku, kus pole midagi ülearust, käsnjat. Jääkidesse, tolknemisse, liigsesse suhtus Semper läbivalt negatiivselt, mis on modernistliku esteetika oluline tunnus. Sekreete, jäätmeid ja siledast nahast eenduvaid kohti kasutas ta tegelaste madaldamiseks. Ühtlasi nähtub jäägifoobia ja teatud kehade hirm nurisünnitusest taastuvast naisekehast: see on eeterliku tantsijatari absoluutne vastand, mis tekitab mehes tülgastust. Niisiis tuleb Semperi keha ja vaimu sulatamise elevust alati täpsustada: milline keha, kelle keha? Samuti on oluline see, kuidas tervikuiha ja sõnavahu vastasus väljendub Semperi stiilinõuetes, kus sallitakse vaid sirgjoonelisust. „Armukadedusega” onnestus tal täita just need ootused, mis ta oli seadnud keelenormidele: romaani kiideti eelkõige laitmatu ja puhta stiili eest.

Semperi ideaalsete naistegelaste eeskujuks sai aga moodne tantsijanna Isadora Duncan, kelle mõju leidub tema esseistikas (eelkõige „Näokatted”), luules (nt „Tantsjanna”) ja ka romaanides (Krista „Armukadeduses”). Modernne tantsijanna seostub nii Bergsoni terviklikkuse ja vitaalsuse filosoofia kui ka Nietzsche dionüüsilise arusaamaga ning aitab taastada harmooniat sõja vägivallast laastatud ja killustunud meestegelastes.

Semperi viimistletud vormiga romaanis „Armukadedus”, milles ta on oma esteetilist programmi rakendanud vahest kõige sügavamalt, ebaõnnestub harmoonia otsing aga sisu tasandil. Armastajate Krista ja Ennu tants - nii koos kui ka eraldi - jääb tantsimata. Võib-olla tasub siin näha peategelaste vahele jäänud seinu ja näokatteid, võib-olla on see Semperi taotluslik käik: mitte kujutada konkreetselt midagi, mis teda kunstilises mõttes sügavalt raputas. Nii jääb tantsijatar kui terviku eeterlik sümbol mõlema tegelase jaoks tabamatuks. Krista ise ei jõua tervikliku elukäsituseni (nii oma mineviku, afäri kui ka lõppkokkuvõttes surma pärast) ning ka Enn ei saavuta ihaldatud tervikut: tema enda keha ja vaim ei ühti ning Kristani lõplikult ta oma sõnul ka ei pürgi.

\section{KIRJANDUS}

Abrams, Meyer H. 1971 [1953]. The Mirror and the Lamp. Romantic Theory and the Critical Tradition. London-Oxford-New York: Oxford University Press.

Adams, Vilmar 1934. Semperi „Armukadedus”. - Üliõpilasleht 20. XI, nr 13, lk 462-464. 
Armstrong, Tim 1998. Modernism, Technology and the Body. A Cultural Study. Cambridge: Cambridge University Press.

Armstrong, Tim 2005. Modernism. A Cultural History. Cambridge: Polity Press.

Bell, Michael 2003. Nietzscheanism: The superman and the all-too-human. - A Concise Companion to Modernism. Toim David Bradshaw. Malden-Oxford-Victoria: Blackwell Publishing, lk 56-74.

Bergson, Henri 2005. Loov evolutsioon. Tlk Margus Ott. (Avatud Eesti raamat.) Tartu: Ilmamaa.

Bergson, Henri 2006. Essee teadvuse vahetutest andmetest. Tlk Margus Ott. (Avatud Eesti raamat.) Tartu: Ilmamaa.

Bergson, Henri 2007. Sissejuhatus metafüüsikasse. Tlk Margus Ott. - Akadeemia, nr 8, lk $1743-1778$.

Carden-Coyne, Ana 2009. Reconstructing the Body. Classicism, Modernism, and the First World War. Oxford: Oxford University Press.

Childs, Peter 2008 [2000]. Modernism. London-New York: Routledge.

Cranny-Francis, Anne; Waring, Wendy; Stravropoulos, Pam; Kirkby, Joan 2003. Gender Studies: Terms and Debates. Basingstoke: Palgrave Macmillan.

Fairer, David 2009. Organising Poetry. The Coleridge Circle, 1790-1798. Oxford: Oxford University Press.

Fuller, Loie 1913. Fifteen Years of a Dancer's Life, With Some Account of Her Distinguished Friends. London: Herbert Jenkins Limited. https://archive.org/details/fifteenyearsofda00fullrich (13. V 2019).

Gillies, Mary Ann 2003. Bergsonism: Time out of mind. - A Concise Companion to Modernism. Toim David Bradshaw. Malden-Oxford-Victoria: Blackwell Publishing, lk 95-115.

Hennoste, Tiit 2016. Eesti kirjanduslik avangard 20. sajandi algul. Hüpped modernismi poole I. (Heuremata.) Tallinn-Tartu: Tartu Ülikooli Kirjastus.

Hinrikus, Mirjam 2013. Modernsuskogemuse kriisist A. H. Tammsaare loomingus ja romaanis „Ma armastasin sakslast”. - Armastus ja sotsioloogia. A. H. Tammsaare romaan „Ma armastasin sakslast”. (Moodsa eesti kirjanduse seminar 2.) Toim M. Hinrikus, Jaan Undusk. Tallinn: Eesti TA Underi ja Tuglase Kirjanduskeskus, lk 11-48.

Hinrikus, Mirjam 2020. Theoretically european and/or upstart? Decadence in an Estonian key. - Nordic Literature and Decadence. Toim Pirjo Lyytikäinen, Riikka Rossi, Viola Parente-Čapková, M. Hinrikus. New York-London: Routledge, lk 175-191.

Hinrikus, Mirjam; Kass, Lola Annabel; Pählapuu, Liis (toim) 2017. Kurja lillede lapsed. Eesti dekadentlik kunst. Tallinn: Eesti Kunstimuuseum, Kumu Kunstimuuseum, Eesti TA Underi ja Tuglase Kirjanduskeskus.

Johnson, Allan 2017. Masculine Identity in Modernist Literature. Castration, Narration, and a Sense of the Beginning, 1919-1945. Basingstoke: Palgrave Macmillan.

Jones, Susan 2009. 'Une écriture corporelle': The Dancer in the text of Mallarmé and Yeats. - The Body and The Arts. Toim Corinne Saunders, Ulrika Maude, Jane Macnaughton. Basingstoke: Palgrave Macmillan, 1k 237-253.

Jones, Susan 2013. Literature, Modernism, and Dance. Oxford: Oxford University Press.

Karelson, Marit 2015. Kui kirjandus jäi aega kinni: sõjast ja kirjandusest Johannes Semperi loomingus. - Esimene maailmasõda eesti kultuuris. (Tallinna Ülikooli eesti keele ja kul- 
tuuri instituudi toimetised 17.) Toim Mirjam Hinrikus, Ave Mattheus. Tallinn: Tallinna Ülikool, Eesti TA Underi ja Tuglase Kirjanduskeskus, lk 261-283.

Kermode, Frank 2004 [1957]. Romantic Image. London-New York: Routledge Classics. Taylor and Francis e-Library.

Kirikal, Merlin 2016. „Uus naine” Johannes Semperi romaanis „Armukadedus”. - Ariadne Lõng, nr 1-2, lk 20-36.

Kirikal, Merlin 2017. Sportlanna keha ja hing Johannes Semperi novellikogus „Ellinor”. - Keel ja Kirjandus, nr 6, lk 417-433.

Kirikal, Merlin 2020 (ilmumas). Pygmalioni ja Narkissose müüdi modernsed tõlgendused: Friedebert Tuglase „Felix Ormusson” (1915) ja Johannes Semperi „Hiina kett” (1918). - „Mäng ja melanhoolia”. Friedebert Tuglase „Felix Ormusson”. Toim Mirjam Hinrikus, Jaan Undusk. Tallinn: Eesti TA Underi ja Tuglase Kirjanduskeskus.

Kivimäe, Jüri 2008. Noor-Eesti tähendust otsides: vanu ja uusi mõtteid. - Methis, nr 1-2, lk 21-41.

Kivimäe, Jüri 2015. Sõda ja kultuuriline pööre. - Esimene maailmasõda eesti kultuuris. (Tallinna Ülikooli eesti keele ja kultuuri instituudi toimetised 17.) Toim Mirjam Hinrikus, Ave Mattheus. Tallinn: Tallinna Ülikool, Eesti TA Underi ja Tuglase Kirjanduskeskus, lk 23-75.

LaMothe, Kimerer L. 2005. „A God Dances Through Me”: Isadora Duncan on Friedrich Nietzsche's Revaluation of Values. - The Journal of Religion, kd 85, nr 2, lk 241-266.

Lyytikäinen, Pirjo; Rossi, Riikka; Parente-Čapková, Viola; Hinrikus, Mirjam 2020. Afterword. The specters of decadence in later nordic literature. - Nordic Literature of Decadence. Toim P. Lyytikäinen, R. Rossi, V. Parente-Čapková, M. Hinrikus. New York-London: Routledge, lk 257-272.

Manning, Susan Allenne; Benson, Melissa 1986. Interrupted continuities: Modern dance in Germany. - The Drama Review: TDR, kd 30, nr 2, lk 30-45.

Nicholls, Peter 2009 [1995]. Modernisms. A Literary Guide. Basingstoke: Palgrave Macmillan.

Nietzsche, Friedrich 1996. Ecce Homo. Kuidas saadakse selleks, mis ollakse. Tlk Jaan Undusk. (Avatud Eesti raamat.) Tartu: Ilmamaa.

Ojam, Indrek 2018. Modernismi muutuv tähendus eesti kirjanduskultuuris. Rekonstrueerimiskatse. - Keel ja Kirjandus, nr 7, lk 541-559.

Ott, Margus 2009. Henri-Louis Bergson. - 20. sajandi mõttevoolud. (Heuremata.) Toim Epp Annus. Tallinn-Tartu: Tartu Ülikooli Kirjastus, lk 85-106.

Posman, Sarah 2013. Modernist energeia: Henri Bergson and the romantic idea of language. - Understanding Bergson, Understanding Modernism. Toim Paul Ardoin, S. E. Gontarski, Laci Mattison. New York-London-New Delhi-Sydney: Bloomsbury, lk 213-227.

Semper, Johannes 1910/11. Sümbolismus ja Saksa romantismus. - Noor-Eesti. Kirjanduse, kunsti ja teaduse ajakiri, nr 5-6, lk 445-467.

Semper, Johannes 1915a. Filosoofilised kirjad. H. Bergson, Aeg ja muutuvus. - Vaba Sõna, nr 1, lk 23-27.

Semper, Johannes 1915b. Filosoofilised kirjad. Sümbool ja reaalsus. - Vaba Sõna, nr 7-8, lk 208-212.

Semper, Johannes 1917. Pierrot. Tallinn: Siuru. 
Semper, Johannes 1918. Hiina kett. Tartu: Odamees.

Semper, Johannes 1919. Näokatted I. Esseede kogu. Tartu: Odamees.

Semper, Johannes 1922. Maa ja mereveersed rytmid. Luuletused 1920-21. Tallinn: Tarapita. Semper, Johannes 1927a. Meie kirjanduse teed. Kirjanduslikud arvustused. Tartu: Loodus. Semper Johannes 1927b. Ellinor. Tartu: Loodus.

Semper, Johannes 1927c. Sillatalad. Tartu: Eesti Kirjanikkude Liidu Kirjastus.

Semper, Johannes 1929. Kolm kehakunsti õhtut „Vanemuises”. - Looming, nr 10, lk 13071309.

Semper, Johannes 1931. Elulähedusest ja vaimulähedusest. - Looming, nr 4, lk 415-424.

Semper, Johannes 1934. Armukadedus. Tartu: Loodus.

Semper, Johannes 1947. Kivi kivi peale. Tallinn: Ilukirjandus ja Kunst.

Semper, Johannes 1971. Tuglast üle lugedes. - J. Semper, Mõtterännakuid II. Teosed VIII. Tallinn: Eesti Raamat, lk 152-166.

Semper, Johannes 1978. Mälestused. Teosed XII. Tallinn: Eesti Raamat.

Siirak, Erna 1969. Johannes Semper. Tallinn: Eesti Raamat.

Tate, Trudi 2013. Modernism, History and the First World War. Penrith: Humanities-Ebooks. Tuglas, Friedebert 2004 [1935]. Eesti romaan 1934. - F. Tuglas, Kogutud teosed 10. Kriitika VII. Kriitika VIII. Tallinn: Underi ja Tuglase Kirjanduskeskus, lk 290-311.

Undusk, Jaan 1997. Tühjusest endasse tõmbavast. Austria eestlase vaimusilmas. - Looming, nr 5, lk 657-679.

Undusk, Jaan 2009. Repertoorium. Saatetekste Tuglase teostele. - Friedebert Tuglas, Valik proosat. Kommenteeritud autoriantoloogia. Koost J. Undusk. Tallinn: Avita, lk 453-677.

Undusk, Jaan 2015. Mälupaik sinepigaas. Esimene maailmasõda, keemiarelv ja kirjandus. Esimene maailmasõda eesti kultuuris. (Tallinna Ülikooli eesti keele ja kultuuri instituudi toimetised 17.) Toim Mirjam Hinrikus, Ave Mattheus. Tallinn: Tallinna Ülikool, Eesti TA Underi ja Tuglase Kirjanduskeskus, lk 195-260.

Walzel, Oskar 1965 [1932]. German Romanticism. Tlk Alma Elise Lussky. New York: Frederick Ungar Publishing Co.

Merlin Kirikal (snd 1986), MA, Tallinna Ülikooli kultuuride uuringute doktorant (Narva mnt 25, 10120 Tallinn), merlinkirikal@gmail.com

\section{Holistic desire and fear of fragmentation in the works of Johannes Semper}

Keywords: gender, body, Henri Bergson, organicism, modern female dancer, World War I

The aesthetic programme of Estonian modernist writer Johannes Semper (18921970) is permeated by ideas of holism and organicism. The article explores what could have motivated/reinforced such a value system and how it might have affected Semper's representations of body and gender. 
From the philosophical point of view Semper's works have been moulded, firstly, by a cognitive strand of German romanticism called organicism, according to which an artistic achievement is also organic, i.e. coming from the living world. Accordingly, an authentic work of art cannot be divided without causing irreparable damage to the whole. Also, it is the opposite of everything artificial. Secondly, Semper was fascinated by Henri Bergson's philosophy, on which basis he insists on the integrity and organic nature of the literary situation, the form of the works and the bodies of the characters. For Semper, Bergson's duration, for example, means an interconnection of phenomena, aims and bodies, recurring in Semper's oeuvre as a chain motif. He also often applies Bergson's concept of intuition, believing that the organic intertwining of life and art, body and spirit, content and form can only be perceived intuitively, not analytically.

Semper's holistic desire and his fear of fragmentation were further enhanced by the material and discursive traumas entailed by the First World War. In literary studies the divisive impact of war is often associated with a compensatory holistic desire, which can also be sensed in Semper's male characters. Thus the characters, together with Semper as implied author, start on a quest for the organic and integral. Those virtues are mainly seen in the body of a dancing female imaged according to Isadora Duncan. For a male spectator the dancing woman appears as an embodiment of organic fusion, where one becomes both body and spirit as well as the dancer and the dance. The activity seems to have no residue, so complete is the fusion. A similar blending, without residue, is a prerequisite of a high-quality literary whole. At the same time the author uses mention of bodily discharges (secretions and excretions) to develop negative associations for certain characters. Such formal pedantry and intolerance against leaking bodies form a gloomy layer of Semper's pathos-laden holism, a layer carrying some meanings deeply rooted in gender and the body.

Merlin Kirikal (b. 1986), MA, Tallinn University, doctoral student in Cultural Studies (Narva mnt 25, 10120 Tallinn), merlinkirikal@gmail.com 